\title{
THE AVOIDANCE OF VACCINATIONS AMONG PEOPLE AGED 0-18 YEARS IN POMORSKIE VOIVODESHIP IN 2000-2017
}

\section{UCHYLANIE SIĘ OD SZCZEPIEŃ OCHRONNYCH WŚRÓD OSÓB W WIEKU 0-18 LAT W WOJEWÓDZTWIE POMORSKIM W LATACH 2000-2017}

\author{
${ }^{1}$ Copernicus Sp. z o.o. Department of Internal Medicine and Hypertension \\ ${ }^{2}$ Voivodeship Sanitary - Epidemiological Station in Gdansk \\ ${ }^{3}$ Medical University of Gdansk, Faculty of Health Sciences with Institute of Maritime and Tropical Medicine, \\ Institute of Maritime and Tropical Medicine, Department of Tropical and Parasitic Diseases \\ ${ }^{1}$ Copernicus Podmiot Leczniczy Sp. z o.o. Oddział Chorób Wewnętrznych i Hipertensjologii \\ ${ }^{2}$ Wojewódzka Stacja Sanitarno-Epidemiologiczna w Gdańsku \\ ${ }^{3}$ Gdański Uniwersytet Medyczny, Wydział Nauk o Zdrowiu z Instytutem Medycyny Morskiej i Tropikalnej, \\ Zakład Medycyny Tropikalnej i Epidemiologii, \\ Uniwersyteckie Centrum Medycyny Morskiej i Tropikalnej, Katedra Medycyny Tropikalnej i Parazytologii
}

\begin{abstract}
INTRODUCTION. The paper analyzes the status of non-vaccination in defiance of the Preventive Vaccination Program. Amongst the factors contributing to the decrease in vaccine uptake in the country are actively working and influential anti-vaccination movements.

MATERIAL AND METHODS. Data obtained from the local epidemiological-sanitary stations was used in the analyses, taking into account numbers, sex, date of birth and type of vaccination.

RESULTS. The analysis includes detailed data from the Pomorskie Voivodeship, where the total number of unvaccinated at 31 December 2017 was 3239 children.

SUMMARY. Over the years the most substantial decrease was observed for the uptake of the MMR, Hep B, polio and DPT vaccines. The rise in vaccine refusal was noted during the years of activity of anti-vaccination movements in the country and in the world.
\end{abstract}

Key words: vaccinations, population, vaccination schedule

\section{STRESZCZENIE}

WSTĘP. W pracy przedstawiono stan niewykonania szczepień zgodnie z obowiązującym w Polsce Programem Szczepień Ochronnych. Do wzrostu liczby uchyleń na terenie kraju przyczyniły się m. in. prężnie działające ruchy antyszczepionkowe.

MATERIALY I METODY. W przedstawionych analizach posłużono się danymi uzyskanymi z powiatowych państwowych stacji sanitarno-epidemiologicznych z uwzględnieniem liczby, płci, roku urodzenia oraz rodzaju szczepienia.

WYNIKI. Analiza obejmuje szczegółowe dane z terenu województwa pomorskiego, gdzie łączna liczba niezaszczepionych na dzień 31 grudnia 2017 r. wynosiła 3239 niezaszczepionych osób.

PODSUMOWANIE. Na przestrzeni lat największą liczbę uchyleń zaobserwowano dla szczepionek MMR, WZW typu B, polio oraz DTP. Wzrost liczby uchyleń obserwowano w latach aktywnego działania ruchów antyszczepionkowych zarówno na terenie kraju jak i w świecie.

Słowa kluczowe: szczepienia, populacja, program szczepień ochronnych. 


\section{INTRODUCTION}

The history of preventive immunization undisputedly proves its effectiveness against dangerous and deadly to humans' contagious diseases, since the development of the vaccination method against smallpox, made by Edward Jenner over 200 years ago. The first attempts to immunize against an infectious disease, which was smallpox, probably date back to the 10th century. The dissemination of preventive immunization is currently one of the most important actions for health promotion, contributing to extending life expectancy throughout inhibiting the spread of infectious diseases $(1,2)$.

Nonetheless, the 21st century brought a lot of challenges. Despite the advantageous epidemiological situation that humanity owes to vaccinations, antivaccination movements have emerged both in the world and in Poland. Members of various associations, presenting themselves as "voluntary vaccination" supporters, refuse to vaccinate themselves or their children. They justify this decision by vaccinations being an overload for a child's immune system due to the supply of too many antigens, detrimental effect of vaccination on the immature immune system, or even the vaccination itself being the sole cause of other diseases, including autism $(3,4)$. Other views on vaccination refer to the myth, that the vaccine against diseases such as diphtheria, tetanus, pertussis or poliomyelitis, contributed to the sudden infant deaths syndrome or a belief that it is better to increase the immunity by undergoing an infection, rather than through a vaccination itself (5).

According to reports of the European Center for Disease Prevention and Control (ECDC), as a result of avoiding vaccination, the number of cases with infectious diseases has visibly increased over the years. For example, in 2015 there were 13519 cases of mumps, in 2016 this number has increased to 14795 cases, invasive meningococcal disease in 2015 - 3121 confirmed cases, in 2016 - 3280 cases $(6,7)$.

On the other hand, there has been many publications throughout renowned scientific journals, presenting results of critical analyzes, questioning those widespread opinions about the negative health effects of vaccination $(8,9,10)$.

In Poland, the analysis of the state of immunization also confirms the decrease in vaccination against infectious diseases, including measles (11). However, in our country, based on the applicable law under which a compulsory preventive vaccination program was established, and according to the Article 17.1 of Prevention and Combating of Contagious Diseases and Infections Act, an obligation to undergo vaccination against infectious diseases, specified in the regulation of the competent Minister of Health, was imposed $(12,13)$.

\section{WSTĘP}

Historia szczepień ochronnych, licząca ponad 200 lat od momentu opracowania metody szczepienia przeciwko ospie prawdziwej przez Edwarda Jennera, bezsprzecznie dowodzi jak skutecznym okazały się one narzędziem w walce z groźnymi i śmiertelnymi chorobami zakaźnymi u ludzi. Pierwsze próby uodpornienia na chorobę zakaźną, jaką była ospa prawdziwa, sięgają najpewniej X wieku. Rozpowszechnianie szczepień ochronnych zajmuje obecnie jedno $\mathrm{z}$ ważniejszych miejsc w promocji zdrowia, przyczyniając się poprzez hamowanie rozprzestrzeniania się chorób zakaźnych, do wydłużenia życia $(1,2)$.

XXI wiek przyniósł jednak wiele wyzwań. Pomimo korzystnej sytuacji epidemiologicznej, którą ludzkość zawdzięcza szczepieniom, zarówno w świecie jak i w Polsce pojawily się ruchy antyszczepionkowe. Członkowie zrzeszeni w różnych stowarzyszeniach, przedstawiający się jako zwolennicy „dobrowolności szczepień", odmawiają zaszczepienia siebie lub dziecka. Decyzję tę motywują przeciążeniem układu odpornościowego małego dziecka w związku z podażą zbyt wielu antygenów, szkodliwością działania szczepienia na niedojrzały układ odpornościowy, czy wywołaniem przez szczepienie innych chorób, w tym autyzmu $(3,4)$. Inne poglądy dotyczące szczepień odnoszą się m.in. do mitu, jakoby szczepionka skojarzona przeciwko błonicy, tężcowi i krztuścowi oraz szczepionka przeciw poliomyelitis przyczyniała się do zespołu nagłej śmierci niemowląt czy przekonania, że lepiej jest zwiększyć swoją odporność przechodząc choroby zakaźne, niż poprzez szczepienie (5).

Jak wynika z raportów Europejskiego Centrum ds. Zapobiegania i Kontroli Chorób (ECDC) w efekcie uchylania się od szczepień, w poszczególnych latach odnotowano zwiększoną liczbę zachorowań na choroby zakaźne. I tak, na przykład w 2015 roku odnotowano 13519 przypadków świnki, w 2016 liczba ta wzrosła do 14795 zachorowań; inwazyjna choroba meningokokowa w 2015 r. - 3121 potwierdzonych przypadków; w 2016 r. -3280 potwierdzonych przypadków $(6,7)$.

W opozycji do mitów o szkodliwości szczepień, w renomowanych czasopismach naukowych publikowane są wyniki krytycznych analiz niepotwierdzających, a nawet podważających szerzone opinie na temat negatywnych skutków zdrowotnych szczepień (8, $9,10)$.

Analiza stanu realizacji szczepień ochronnych w Polsce również potwierdza spadek wyszczepialności na choroby zakaźne, w tym np. na odrę (11). Jednakże w naszym kraju, na podstawie obowiązującego przepisu prawa, z mocy którego powstał obowiązkowy program szczepień ochronnych oraz na podstawie ar- 


\section{THE AIM OF THE STUDY}

The aim of this paper was to present a detailed analysis of lack of compliance with the Preventive Vaccination Program, obligatory in Poland, in Pomorskie Voivodeship in 2000-2017 among people of the age $0-18$, broken down by individual types of vaccinations. The data presented with simple histograms, was obtained from the Voivodeship Sanitary and Epidemiological Station (2000-2017; as of 31.12.2017) and relates to the scale of unvaccinated children between the age of $0-18$. Thereby the scale of the vaccination avoidance problem was presented, together with the risk of developing those infectious diseases, for which a very significant reduction of incidence was achieved in the past century.

\section{MATERIALS AND METHODS}

Retrospective analysis covers the data obtained from the Local Sanitary and Epidemiological Stations in Pomorskie Voivodeship collected throughout the years 2000-2017.

Data concerning the number, sex, year of birth and the type of vaccination, which has not been administered to children, derive from submitted statistics. Due to a retrospective nature of the analysis, it is not possible to clearly determine the reason why the statutory obligation to vaccinate in those cases had been evaded, including the influence on parents' decisions.

The figures presented in this paper relate to the repeals of the immunization program, where 1 repeal concerns 1 dose of vaccine per 1 child.

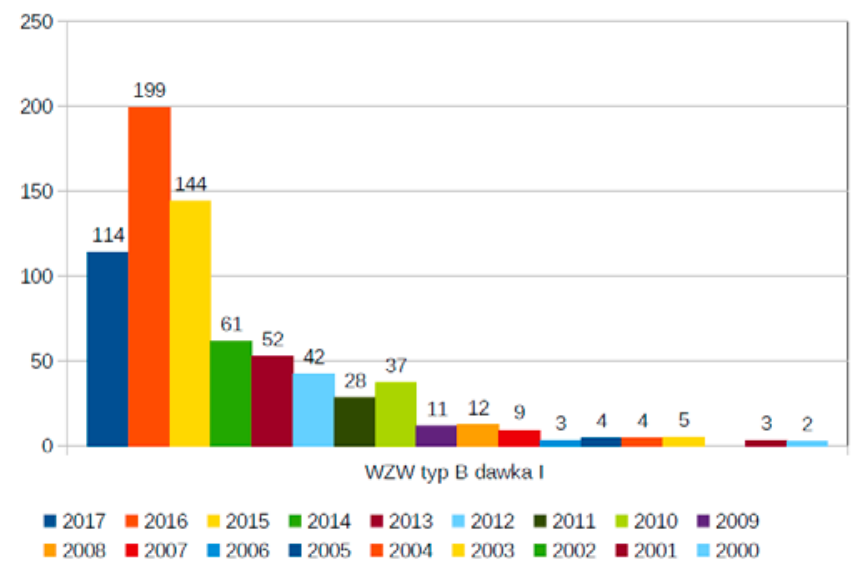

Fig. 1. Number of unvaccinated on hepatitis B dose I in Pomorskie voivodeship in 2000-2017 years.

Ryc. 1. Liczba niezaszczepionych przeciwko WZW typu B dawką I w województwie pomorskim w latach 2000-2017. tykułu 17.1 Ustawy o zapobieganiu oraz zwalczaniu zakażeń i chorób zakaźnych u ludzi, nałożony został obowiązek poddania się szczepieniom przeciwko chorobom zakaźnym określonym w rozporządzeniu właściwego Ministra Zdrowia $(12,13)$.

\section{CEL PRACY}

Celem niniejszej pracy była szczegółowa analiza niewykonania szczepień zgodnie $\mathrm{z}$ obowiązującym w Polsce Programem Szczepień Ochronnych na terenie województwa pomorskiego w latach 2000-2017 wśród osób w wieku 0-18 lat, z podziałem na określone szczepienia. Na podstawie prostych histogramów przedstawiono dane pozyskane z Wojewódzkiej Stacji Sanitarno-Epidemiologicznej (lata: 2000-2017; stan na 31.12.2017 roku) dotyczące niezaszczepionych dzieci w wieku 0-18 lat. Zebrane dane mają zobrazować skalę problemu uchylania się od szczepień oraz wskazać na ryzyko rozwoju tych chorób zakaźnych, co do których osiągnięto $\mathrm{w}$ minionym stuleciu bardzo znaczne zmniejszenie zapadalności.

\section{MATERIAŁY I METODY}

Analiza retrospektywna objęła dane uzyskane z powiatowych stacji sanitarno-epidemiologicznych w województwie pomorskim, zgromadzone w latach 2000-2017.

Dane dotyczące liczby, płci, roku urodzenia oraz szczepienia, od którego odstąpiono u dziecka czerpano z nadesłanych statystyk. Ze względu na retrospektywny charakter analizy, nie można jednoznacznie określić przyczyny uchylenia się od ustawowego obowiązku szczepienia, w tym wpływu na decyzję rodziców.

Przedstawione w niniejszym artykule dane liczbowe dotyczą uchyleń od programu szczepień ochronnych, gdzie 1 uchylenie dotyczy 1 dawki szczepionki przypadające na 1 dziecko.

\section{WYNIKI}

W okresie od 1 stycznia 2000 do 31 grudnia 2017 roku na terenie województwa pomorskiego zarejestrowano łącznie 3239 uchyleń od szczepień dzieci w wieku od 0 do 18 roku życia, co stanowi $0,62 \%$ wszystkich osób w wieku 0-18 lat zamieszkałych w tymże województwie, które nie zostały zaszczepione zgodnie z Programem Szczepień Ochronnych. Pośród zarejestrowanych uchyleń chłopcy w liczbie 1742 stanowili 53,7\%, natomiast dziewczęta w liczbie 1497 pozostałe $46,3 \%$. Na podstawie zebranych danych można zauważyć, że liczba uchyleń wśród chłopców i dziewczynek na przestrzeni lat 2000-2017 jest porównywalna. 


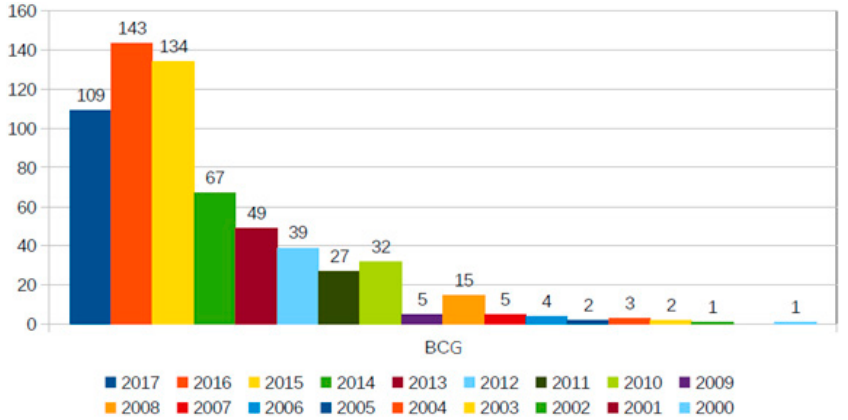

Fig. 2. Number of unvaccinated on tuberculosis in Pomorskie Voivodeship in 2000-2017 years.

Ryc. 2. Liczba niezaszczepionych przeciwko BCG (gruźlica) w województwie pomorskim w latach 2000-2017.

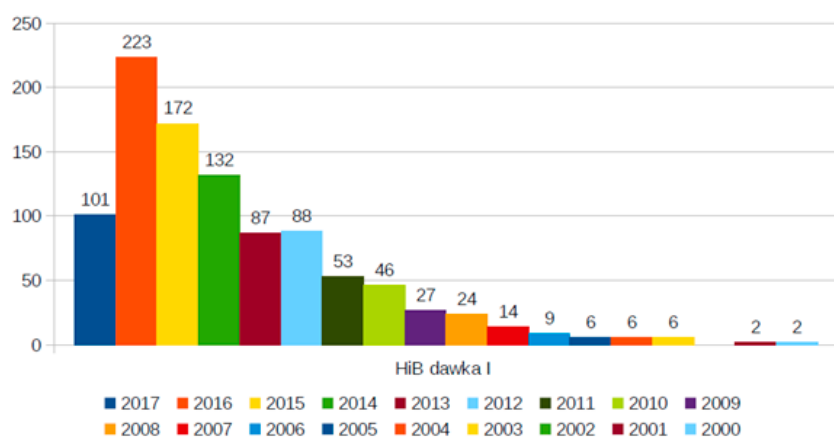

Fig. 3. Number of unvaccinated on Haemophilus influenzae dose I in Pomorskie voivodeship in 2000-2017 years.

Ryc. 3. Liczba niezaszczepionych przeciwko zakażeniom Haemophilus influenzae dawką I w województwie pomorskim w latach 2000-2017.

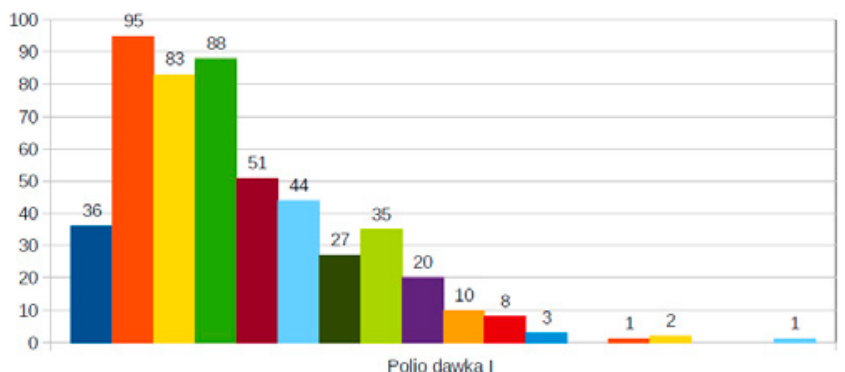

| 2017 | 2016 | 2015 || 2014 | 2013 || 2012 || $2011=2010$ | 2009

= $2008=2007$ | $2006=2005=2004=2003=2002=2001=2000$

Fig. 4. Number of unvaccinated on poliomyelitis dose I in Pomorskie Voivodeship in 2000-2017 years.

Ryc. 4. Liczba niezaszczepionych na poliomyelitis dawką I w województwie pomorskim w latach 2000-2017.

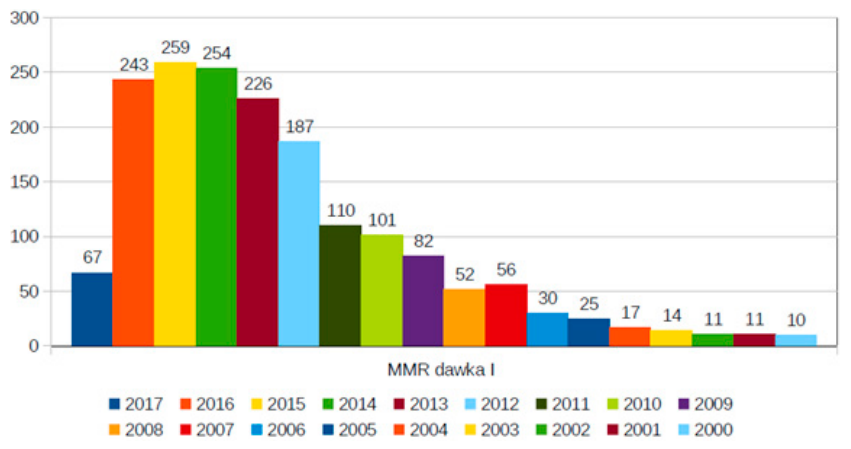

Fig. 5. Number of unvaccinated on measles-mumps-rubella dose I in Pomorskie Voivodeship in 2000-2017 years.

Ryc. 5. Liczba niezaszczepionych przeciwko odrze, śwince, różyczce dawką I w województwie pomorskim w latach 2000-2017.
Dokonując szczegółowej analizy zgromadzonych danych można zaobserwować stopniowy wzrost uchyleń w poszczególnych latach. Znaczący wzrost uchyleń na terenie województwa pomorskiego zaobserwowano w roku 2012, w którym to w stosunku do roku poprzedniego odnotowano wzrost aż o 76 przypadków uchyleń wśród dzieci obojga płci. W kolejnych latach obserwowano tendencję wzrostową, jednak w roku 2017 zarejestrowano spadek bezwzględnej liczby uchyleń od programu szczepień ochronnych. W oparciu o zgromadzone dane przeprowadzono szczegółowe analizy uchyleń w latach 2012-2017.

W roku 2012 szczepieniem, od którego najczęściej odstępowano, była pierwsza dawka szczepionki przeciwko odrze, śwince i różyczce - zanotowano łącznie 187 uchyleń. Stosunkowo wysoko w liczbie uchyleń były: dawka czwarta szczepionki skojarzonej przeciwko błonicy, tężcowi i krztuścowi - 100 osób; dawka pierwsza przeciwko błonicy, tężcowi, krztuścowi, dawka czwarta Haemophilus influenzae oraz dawka trzecia polio - dla każdej 92 osoby; dawka pierwsza Haemophilus influenzae - 88 osób. W 2012 roku nie zanotowano uchylania się od szczepienia drugą dawką przeciwko odrze, śwince, różyczce oraz drugą dawką przypominającą przeciwko błonicy i tężcowi.

Rok 2013 przyniósł wzrost liczby uchyleń. Podobnie jak w roku poprzednim dominującym szczepieniem, od którego odstępowano w przypadku obu płci była pierwsza dawka szczepionki przeciwko odrze, śwince, różyczce - zanotowano 226 uchyleń. W tym samym roku zaobserwowano uchylenia od czwartej dawki szczepionki przeciwko błonicy, tężcowi i krztuścowi (171 uchyleń), trzeciej dawki przeciwko poliomyelitis (165 uchyleń) oraz czwartej dawki przeciwko Haemophilus influenzae (158 uchyleń). Odnotowano po jednym przypadku uchylania się od szczepienia skojarzoną szczepionką błonica, tężec, krztusiec i poliomyelitis dawką pierwszą przypominającą wśród obu płci. W 2013 roku nie odnotowano natomiast uchyleń od szczepień drugą dawką MMR oraz dawką drugą przypominającą przeciwko błonicy, tężcowi u obu płci.

W roku 2014 dominuje uchylanie się od szczepienia dawką pierwszą przeciwko odrze, śwince, różyczce. W opracowanych zestawieniach można było zaobserwować wysokie wskaźniki uchyleń dla szczepienia dawką czwartą przeciwko błonicy, tężcowi, krztuścowi (144 uchyleń), dawką czwartą przeciwko Haemophilus influenzae (129 uchyleń), dawką trzecią poliomyelitis (133 uchyleń), pierwszą dawką DTP (123 uchyleń) oraz pierwszą dawką przeciwko Haemophilus influenzae (122 uchyleń). Rok 2014 jest okresem, w którym zanotowano dodatkowo jeden przypadek uchylania się od obowiązkowego szczepienia skojarzoną szczepionką przeciwko błonicy, tężcowi, krztuścowi (DTPa), dwa przypadki odstapienia od szczepienia przeciwko poliomyelitis dawką pierwszą przypominającą i jedno uchylenie się od szczepienia MMR dawką drugą. Odstępstwa te dotyczą jedynie dziewcząt. 


\section{RESULTS}

During the period from January 1, 2000 to December 31, 2017, a total of 3239 waivers from vaccination of children between the age of $0-18$ have been registered in the Pomorskie Voivodeship, which is $0,62 \%$ of all people aged $0-18$ residing in that voivodeship that have not been vaccinated in compliance with the Immunization Program. Amongst the registered waivers, 1742 boys represent $53,7 \%$ of the overall number, while girls in 1497 represent the remaining $46,3 \%$. Based on the collected data it is noticeable, that the number of waivers among boys and girls over the years 2000-2017 is comparable. After a detailed analysis of the collected data, gradual increase in repeals can beobserved throughout the individual years. A significant increase in repeals in the Pomorskie Voivodeship was observed in 2012, when compared to the previous year, there was an increase by 76 cases of repeals among children of both sexes. An upward trend was observed in subsequent years, however in 2017 a decrease in the absolute number of waivers from the immunization program was recorded. Based on the collected data, detailed analyses of repeals were carried out in 2012-2017.

In 2012, the most common vaccination to be resigned from, was the dose I against measles, mumps and rubella - in total 187 cases of repeal. Relatively high, as far as the number of repeals is concerned, were also: dose IV of the combined vaccine against diphtheria, tetanus and pertussis - in the number of 100 people; dose I against diphtheria, tetanus and pertussis, dose IV of Haemophilus influenzae and dose III of polio - in each 92 people; dose I of Haemophilus influenzae - 88 people. In 2012, there were no cases of evasion of dose II against measles, mumps, rubella, and second booster dose against diphtheria and tetanus.

The year 2013 brings a gradual increase in the number of repeals. Analogically to the prior year, the vaccination most common to be waived for both sexes, was the dose I against measles, mumps and rubella - 226 repeals noted. During the same year, repeals from the dose IV against diphtheria, tetanus and pertussis vaccine (171 repeals), dose III against poliomyelitis (165 repeals) and dose IV against Haemophilus influenzae (158 repeals) were observed. One case of repeal from the combined vaccine against diphtheria, tetanus, pertussis and first booster dose against poliomyelitis amongst both sexes has been reported. Nonetheless, in 2013, there were no cases of avoidance as far as the dose II against MMR and the second booster dose against diphtheria and tetanus are concerned, both sexes being considered.

In 2014 , the most avoided vaccinations are those against measles, mumps and rubella (dose I). Within the reports, high abrogation rates for vaccines such
W 2015 roku największą liczbę uchyleń odnotowano dla pierwszej dawki szczepionki przeciwko odrze, śwince, różyczce - u 259 dzieci. Innymi szczepieniami, względem których odnotowano najwyższą liczbę uchyleń były szczepienia przeciwko: błonicy, tężcowi, krztuścowi dawka pierwsza (176 uchyleń), Haemophilus influenzae dawka pierwsza (172 uchylenia), WZW typu B dawka pierwsza (144 uchylenia) oraz gruźlica (134 uchylenia). W roku 2015 nie odnotowano uchyleń od szczepionek DTPa, poliomyelitis pierwsza dawka przypominająca, MMR - dawka druga oraz błonica, tężec - dawka druga przypominająca.

Nieco inny obraz prezentują dane z 2016 roku, w którym na terenie województwa pomorskiego odnotowano największą liczbę przypadków dzieci niezaszczepionych przeciwko WZW typu B dawką pierwszą szczepionki. W okresie badanych 17 lat jest to najwyższy wskaźnik - 294 dzieci obojga płci, u których nie wykonano szczepienia zgodnie z PSO. Podobnie jak w latach poprzednich odnotowano stosunkowo dużą liczbę uchyleń od szczepienia dawką pierwszą MMR (243 uchylenia), dawką pierwszą DTP (224 uchylenia) oraz dawką pierwszą przeciwko $\mathrm{Ha}$ emophilus influenzae (223 uchylenia). Rok 2016 to okres, w którym nie zarejestrowano osób uchylających się od szczepienia skojarzoną szczepionką błonica, tężec, krztusiec (DTPa), poliomyelitis dawką pierwszą przypominającą oraz drugą dawką przeciwko odrze, śwince, różyczce. W porównaniu do poprzednich lat, w grupie dziewcząt odnotowano jedno uchylenie się od szczepienia przeciwko błonicy i tężcowi dawką drugą przypominającą.

W 2017 roku powiatowe stacje sanitarno-epidemiologiczne zarejestrowały znaczny wzrost uchyleń od szczepień przeciwko WZW typu B dawką pierwszą (114 uchyleń) i przeciwko gruźlicy (99 uchyleń). Odstąpienia od wykonywanych szczepień dotyczyły również szczepienia przeciwko błonicy, tężcowi, krztuścowi (105 uchyleń) i Haemophilus influenzae dawką pierwszą (99 uchyleń). W 2017 roku odnotowano po jednym przypadku uchyleń od szczepień DTP dawką czwartą, Haemophilus influenzae dawką czwartą oraz poliomyelitis dawką trzecią. Natomiast nie zarejestrowano uchyleń od szczepień skojarzoną szczepionką błonica, tężec, krztusiec (DTPa), poliomyelitis dawką pierwszą przypominającą, odra, świnka, różyczka dawką drugą oraz błonica, tężec dawką drugą przypominającą.

Powyżej zamieszczono histogramy prezentujące zależność pomiędzy rodzajem szczepienia, dawką szczepionki, a badanym okresem (Ryc.1-5). Dokonując analizy przedstawionych rycin na osi czasu widać zmieniające się tendencje w wyborze szczepień, od których się uchylono. 
as dose IV against diphtheria, tetanus, pertussis (144 repeals), dose IV against Haemophilus influenzae (129 repeals), dose III of poliomyelitis (133 repeals), dose I of DTP (123 repeals) and dose I against Haemophilus influenzae (122 repeals) can be observed. The year 2014 is the period, in which an additional one case of evasion of compulsory vaccination with the combined vaccine against diphtheria, tetanus, pertussis (DTPa), two cases of repeal from poliomyelitis with the first booster dose and one repeal from dose II of MMR vaccination were recorded. These abrogations apply only to girls.

\section{OMÓWIENIE WYNIKÓW}

Zaprezentowane wyniki badań pokazały wysoki odsetek osób niezaszczepionych nie tylko w województwie pomorskim, ale i ogólnopolski wzrost bezwzględnej liczby niezaszczepionych (Tab. I). Na przestrzeni lat obserwowano zmieniające się trendy w zależności od rodzaju szczepienia, od którego odstępowano. W prezentowanych wynikach zdecydowany prym w liczbie uchyleń wiodą szczepionki MMR, WZW typu B, polio, a także DTP.

Table I. Comparison of the number of people covered by vaccination obligation to the total number of unvaccinated in individual provinces of Poland - state on 31 December 2017.

Tabela I. Porównanie liczby osób objętych obowiązkiem szczepienia do całkowitej liczby uchyleń od szczepień w poszczególnych województwach w Polsce - stan na 31 grudnia 2017 roku.

\begin{tabular}{|c|c|c|c|}
\hline Województwo & $\begin{array}{c}\text { Liczba osób objętych } \\
\text { obowiązkiem szczepienia }\end{array}$ & Liczba uchyleń & \% uchyleń \\
\hline Dolnośląskie & 515524 & 1938 & 0,38 \\
\hline Kujawsko-pomorskie & 398054 & 887 & 0,22 \\
\hline Lubelskie & 400409 & 1550 & 0,04 \\
\hline Lubuskie & 194005 & 851 & 0,44 \\
\hline Łódzkie & 441203 & 1182 & 0,27 \\
\hline Małopolskie & 676886 & 1645 & 0,24 \\
\hline Mazowieckie & 10613387 & 4559 & 0,04 \\
\hline Opolskie & 129491 & 760 & 0,06 \\
\hline Podkarpackie & 414290 & 136 & 0,03 \\
\hline Podlaskie & 218467 & 1908 & 0,87 \\
\hline Pomorskie & 476310 & 3239 & 0,68 \\
\hline Śląskie & 810993 & 5395 & 0,67 \\
\hline Świętokrzyskie & 221094 & 376 & 0,17 \\
\hline Warmínsko-mazurskie & 279323 & 964 & 0,35 \\
\hline Wielkopolskie & 708920 & 4332 & 0,61 \\
\hline Zachodniopomorskie & 311730 & 799 & 0,26 \\
\hline Ogółem & $\mathbf{1 6 8 1 0 0 8 6}$ & $\mathbf{3 0 5 2 1}$ & $\mathbf{0 , 1 8}$ \\
\hline
\end{tabular}

Źródło: opracowanie własne na podstawie informacji pozyskanych z wojewódzkich stacji sanitarno-epidemiologicznych.

In 2015, the largest number of repeals was recorded in relation to dose I against measles, mumps and rubella vaccines - 259 children. Other vaccinations, for which the highest number of repeals have been recorded, were diphtheria, tetanus, pertussis dose I (176 repeals), Haemophilus influenzae dose I (172 repeals), hepatitis B dose I (144 repeals) and tuberculosis (134 repeals). In 2015, there were no repeals from DTP vaccines, poliomyelitis - the first booster dose, MMR - dose II and diphtheria, tetanus - the second booster dose.

A slightly different situation is presented by 2016 data, where the largest number of children, unvaccinated against hepatitis B with the first dose of
Zbiorcze raporty prezentujące liczby niezaszczepionych $\mathrm{w}$ poszczególnych województwach zgodnie z obowiązującym w Polsce Programem Szczepień Ochronnych, wskazują na potencjalny wzrost zapadalności na choroby zakaźne, stanowiący istotne zagrożenie dla zdrowia publicznego w skali całego kraju. Województwo pomorskie w skali ogólnopolskiej zajmuje w 2017 roku czwarte miejsce z liczbą 3239 uchyleń, ustępując miejsca województwu śląskiemu - ogółem 5395 uchyleń, województwu mazowieckiemu - ogółem 4559 uchyleń i wielkopolskiemu - ogółem 4332 uchylenia.

Obserwowany na terenie województwa pomorskiego stopniowy wzrost liczby dzieci, u których odstą- 
vaccine, was recorded in the Pomorskie Voivodeship. Within the examined period of 17 years, this is the highest rate - 294 children of both sexes, who were not vaccinated in compliance with the Preventive Vaccination Plan. As in previous years, a relatively large number of repeals from vaccination with the first dose of MMR (243 repeals), the first dose of DTP (224 repeals) and the first dose against Haemophilus influenzae (223 repeals) were recorded. The year 2016 was the period, in which there have not been any cases of repeals as far as above vaccinations are concerned: the combined vaccine against diphtheria, tetanus, pertussis (DTPa), poliomyelitis with the first booster dose and the dose II against measles, mumps and rubella. In comparison to previous years, there was one case of evasion of diphtheria and tetanus vaccination amongst girls (with the second booster dose).

In 2017, local sanitary and epidemiological stations recorded a significant increase in repeal of vaccination against hepatitis B dose I (114 repeal) and against tuberculosis (99 repeals). Repeals from vaccinations concerned also vaccination against diphtheria, tetanus, pertussis (105 repeals) and Haemophilus influenzae dose I (99 repeals). In 2017, there was one case of repeal of DTP vaccinations dose IV, Haemophilus influenzae dose IV and poliomyelitis dose III. However, no vaccination waivers were registered with the combined vaccine diphtheria, tetanus, pertussis (DTPa), poliomyelitis with the first booster, measles, mumps, rubella dose II and diphtheria, tetanus with the second booster.

The histograms above show the relationship between the type of vaccination, vaccine dose and the studied period (Fig. 1-5). While analyzing the figures presented on the timeline, there is a visible change of trends in the range of vaccinations that have been evaded.

\section{DISCUSSION}

The research results showed not only a high percentage of unvaccinated individuals in the Pomorskie Voivodeship but also a nationwide increase in the number of unvaccinated cases (Table I). Over the years, trends concerning each type of vaccination to be refused, have been changing. The results show that MMR, hepatitis B, polio, and DTP vaccines are clearly the most common to be ignored when it comes to numbers.

Aggregated reports presenting the numbers of unvaccinated individuals in various voivodeships, in accordance with the obligatory Preventive Vaccination Program in Poland, show the potential increase in the incidence of infectious diseases, which piono od ustawowego obowiązku szczepień przypada m.in. na lata aktywnego działania zarówno w świecie, jak i w naszym kraju wspomnianych już ruchów antyszczepionkowych. W Sejmie RP interesy antyszczepionkowców reprezentuje powstały w lutym 2016 roku Parlamentarny Zespół ds. Bezpieczeństwa Programu Szczepień Ochronnych Dzieci i Dorosłych, stawiający sobie między innymi za cel tzw. krzewienie „rzetelnej wiedzy o szczepieniach" (14). Zespół ten ściśle współpracuje ze wspomnianym już stowarzyszeniem STOP NOP umożliwiając mu realizację założeń statutowych, czego efektem był obywatelski projekt ustawy znoszący obowiązek szczepień, który do Sejmu RP wpłynął w lipcu 2018 r. i został odrzucony w listopadzie 2018 r.

Głoszona przez stowarzyszenie STOP NOP teoria szkodliwości szczepień $\mathrm{w}$ pierwszych dobach życia m.in. przeciwko gruźlicy i WZW B nie odnalazła faktycznego i naukowego poparcia. Z historii szczepień wiadomo, że opracowanie preparatu szczepionki przeciwko WZW typu B przez M. Hillemana było znaczącym osiągnięciem cywilizacyjnym. Poprzez uodpornienie najmłodszej populacji, najbardziej narażonej na następstwa trwającego wiele lat, często skąpo lub bezobjawowego przewlekłego WZW B, przyczyniło się do zmniejszenia zapadalności na marskość wątroby i raka wątrobowokomórkowego (15).

Podobnie, bazując na licznych dowodach, niezrozumiałe jest uchylanie się rodziców od szczepień dzieci i młodzieży przeciwko poliomyelitis. Nieobowiązujące od roku 2016 szczepienie dzieci żywą szczepionką przeciwko poliomyelitis zastąpiono szczepionką inaktywowaną, co stanowi wysoce bezpieczną formę uodpornienia. Aktualnie obserwowane załamanie progu wyszczepialności może przyczynić się do utraty kontroli nad transmisją wirusa $\mathrm{w}$ środowisku. Wysoka zaraźliwość wirusa poliomyelitis w połączeniu ze wzrostem odsetka osób/dzieci podatnych na zakażenie może otworzyć drogę do wzrostu zapadalności na chorobę, która rzadko, ale może być przyczyną zgonu w mechanizmie niewydolności oddechowej oraz której następstwem jest ciężkie i trwałe inwalidztwo ruchowe wśród chorujących dzieci (16).

Mimo wycofania w roku $2010 \mathrm{z}$ czasopisma The Lancet doniesienia Wakefield 'a i uznania go za nierzetelnego lekarza i naukowca warto wspomnieć o późnych następstwach jego działań, którymi są m.in. opublikowane w lutym 2018 roku przez ECDC podsumowanie danych epidemiologicznych za rok 2017 wykazujące 3-krotny wzrost zachorowań na odrę w krajach europejskich (17). Ta niekorzystna sytuacja epidemiologiczna jest najpewniej odzwierciedleniem wzrostu liczby dzieci nieszczepionych szczepionką MMR w różnych krajach Europy. Skłania to do wnioskowania, że błędnie szerzony pogląd o szkodliwości szczepienia przeciwko odrze, śwince, różyczce stał się 
is a substantial threat to public health on a national scale. In 2017, the Pomorskie Voivodeship takes the fourth place in Poland with the number of 3239 waivers, giving way to Śląskie Voivodeship - 5395 waivers in total, Mazowieckie Voivodeship - a total of 4559 repeals and the Wielkopolskie Voivodeship - a total of 4332 repeals.

A gradual increase, concerning the number of children, who have waived the statutory obligation of immunization observed in the Pomorskie Voivodeship, coincides with the years of the already mentioned anti-vaccination movements' activity, both in the world and in our country. In Polish parliament, the anti-vaxxers' interests are represented by the Parliamentary Team for the Safety of the Vaccination Program for Children and Adults, established in February 2016 and aiming, among other things, at promoting 'honest knowledge about vaccinations' (14). This team strictly cooperates with the already mentioned STOP NOP association, enabling the implementation of its statutory guidelines, which resulted in a citizen bill initiative abolishing the obligatory vaccination, presented to the parliament in July 2018 and rejected in November 2018.

The theory preached by the STOP NOP association, depicting vaccines as harmful, especially in child's first days of life, among others the vaccine against tuberculosis and hepatitis B, did not find any virtual and scientific support. As we know from the history of vaccination, the development of the vaccine against hepatitis B, made by M. Hilleman, was a significant civilization achievement. By immunizing the youngest population, most vulnerable to the tragic and irreversible consequences of frequently asymptomatic chronic hepatitis $\mathrm{B}$, has contributed to reducing the incidence of liver cirrhosis and hepatocellular carcinoma (15).

Similarly, based on numerous evidences, parents' evasion of vaccinating children and adolescents against poliomyelitis is incomprehensible. Vaccinating children using a live vaccine against poliomyelitis, which has not been binding since 2016, has been replaced with an inactivated one, which is a highly safe form of immunization. Currently observed collapse of the vaccination threshold may contribute to loss of control over virus transmission in the environment. The high contagiousness of the poliomyelitis virus combined with the increase of the percentage of children susceptible to infection, may be the reason for higher incidence of the disease, which rarely but still, may be the cause of death in the mechanism of respiratory failure, and which results in severe and permanent mobility disability among sick children (16). problemem globalnym (18). Według WHO w samym 2018 roku w Europie odnotowano 41 tysięcy zachorowań na odrę, z czego, jak wynika z danych prezentowanych przez Narodowy Instytut Zdrowia Publicznego - Państwowy Zakład Higieny, w Polsce zgłoszono 339 przypadków zachorowań na tę chorobę (19).

\section{PODSUMOWANIE}

1. Analiza danych - stan niezaszczepionych na dzień 31 grudnia 2017 roku - uzyskanych z Powiatowych Stacji Sanitarno-Epidemiologicznych pokazuje trend uchylania się od ustawowego obowiązku szczepień w województwie pomorskim, a tym samym alarmuje o niebezpieczeństwie związanym z szerzeniem się chorób zakaźnych.

2. W grupie mieszkańców województwa pomorskiego w wieku 0-18 lat, liczącej w 2017 roku według Głównego Urzędu Statystycznego 476310 osób, odnotowano ogółem 3239 przypadków osób niezaszczepionych z powodu uchylania się rodziców od szczepienia dzieci.

3. Szczegółowa analiza rodzaju szczepienia, od którego najczęściej odstępowano w latach 20122017, wykazała największą niechęć do szczepienia przeciwko odrze, śwince, różyczce, co łączy się z okresem prężnego działania ruchu antyszczepionkowego i głoszenia przez jego członków teorii szkodliwego działania szczepionki MMR na centralny układ nerwowy.

4. Na terenie województwa pomorskiego odnotowano również wysoki odsetek uchylania się od szczepienia przeciwko WZW typu B, co w konsekwencji może skutkować wzrostem liczby chorych na raka wątrobowokomórkowego w przyszłości.

5. Na podstawie zgromadzonych informacji, pozyskanych z WSSE w Gdańsku ustalono, że wszystkie dzieci, tj. 3239 osób, nie poddano szczepieniu ze względu na brak zgody rodziców na wykonanie procedury zgodnie z PSO.

\section{REFERENCES}

1. Bednarek A., Emeryk-Bartkowiak M., Wysocki J. Szczepienia ochronne w profilaktyce chorób zakaźnych u dzieci, Wyd. I. Warszawa: Wydawnictwo PZWL, 2018.

2. Stanowisko Krajowego Konsultanta w dziedzinie Zdrowia Publicznego ws. obowiązku szczepień. Pobrane z: https://gis.gov.p1/zdrowie/stanowisko -krajowego-konsultanta-w-dziedzinie-zdrowia -publicznego-ws-obowiazku-szczepien/

3. Augustynowicz, E., Stefanoff P. (2019) Mity na temat szczepionek. Pobrane z: https://szczepienia. pzh.gov.pl/wszystko-o-szczepieniach/popularne -mity-temat-szczepien/ 
Despite the 2010 Wakefield's' reports withdrawal from The Lancet magazine, and recognizing him as an unreliable physician and scientist, it is worth mentioning the consequences of his actions, which are among others, a summary of the epidemiological data for 2017 published in February 2018 by the ECDC showing a threefold increase in measles incidence in European countries (17). This unfavorable epidemiological situation is most likely a reflection of the increase in the number of children unvaccinated with the MMR vaccine in various European countries. This leads to the conclusion, that the erroneously widespread view of the harmfulness of vaccination against measles, mumps or rubella, has become a global problem (18). According to WHO, in 2018 alone in Europe, 41 thousand cases of measles were reported, of which, according to data presented by the National Institute of Public Health - National Institute of Hygiene, 339 cases of this disease were reported in Poland (19).

\section{SUMMARY}

1. Data analysis - unvaccinated status as at December 31, 2017 - obtained from the Local Sanitary and Epidemiological Stations shows a trend of evading the statutory obligation to vaccinate in the Pomorskie Voivodeship, and thus alerts about the danger associated with the spread of infectious diseases.

2. In the group of 476310 residents of the Pomorskie Voivodeship aged 0-18 years in 2017, according to the Central Statistical Office, a total of 3239 cases of unvaccinated individuals, due to parents' evasion of vaccination, were recorded.

3. A detailed analysis of the type of vaccination, which was most often waived in the years 20122017, showed the greatest reluctance to vaccinate against measles, mumps and rubella, which is associated with a period of dynamic activity of the anti-vaccination movement, proclaiming the harmfulness of vaccines against MMR on the central nervous system.

4. In the Pomorskie Voivodeship, high percentage of people unvaccinated against hepatitis B was also reported, which may result in an increase in the number of patients with hepatocellular carcinoma in the future.

5. Based on the collected information, obtained from the WSSE in Gdansk, it was found that all children, i.e. 3239 individuals, were not vaccinated due to parents' disagreement to perform the procedure in accordance with the Preventive Vaccination.
4. Czajka H. (2010) Szczepienia u dzieci fakty i mity. Pobrane z: https://www.mp.pl/pacjent/szczepienia/ sytuacje-szczegolne/70468,szczepienia-u-dzieci -fakty-i-mity

5. Państwowa Inspekcja Sanitarna w Lodzi, Mity i fakty na temat szczepień - http://pis.lodz.pl/data/ other/mity_i_fakty_szczepienia.pdf

6. Steffanoff, P. (2017) ECDC opublikowało raporty roczne o występowaniu chorób zakaźnych w Europie w 2015r. Pobrane z: https://szczepienia.pzh. gov.pl/europejskie-centrum-prewencji-kontroli -chorob-ecdc-sztokholmie-opublikowalo-raporty-roczne-o-wystepowaniu-chorob-zakaznych2015-roku/

7. Narodowy Instytut Zdrowia Publicznego - Państwowy Zakład Higieny (2018). ECDC opublikowało raporty roczne o występowaniu chorób zakaźnych w Europie w 2016 r. Pobrane z: https:// szczepienia.pzh.gov.pl/ecdc-opublikowalo-raporty-roczne-o-wystepowaniu-chorob-zakaznych-w -europie-2016-roku/

8. Becerra-Culqui TA, Getahun D, Chiu V et al. Prenatal Tetanus, Diphtheria, Acellular Pertussis Vaccination and Autism Spectrum Disorder. Pediatric 2018; 142(3) doi: 10.1542/peds.2018-0120.

9. Uno Y, Uchiyama T, Kurosawa M, et al. Early exposure to the combined measles-mumps-rubella vaccine and thimerosal-containing vaccines and risk of autism spectrum disorder. Vaccine. 2015 May 15;33(21):2511-6. doi:10.1016/j.vaccine.2014.12.036. Epub 2015 Jan 3.

10. Statut ogólnopolskiego stowarzyszenia wiedzy o szczepieniach STOP NON (2017). Pobrane z: https://stopnop.com.pl/statut-ogolnopolskiego-stowarzyszenia-wiedzy-o-szczepieniach-stop-nop/

11. Solecka M. (2018) Polska poniżej bezpiecznego poziomu wyszczepialności. Pobrane z: https://www. mp.pl/szczepienia/aktualnosci/185842,polska-ponizej-bezpiecznego-poziomu-wyszczepialnosci

12. Obwieszczenie Ministra Zdrowia z dnia 28 marca 2018 r. w sprawie ogłoszenia jednolitego tekstu rozporządzenia Ministra Zdrowia w sprawie obowiązkowych szczepień ochronnych - Dz.U. 2018 poz.753. Pobrane z: http://prawo.sejm.gov.pl/isap. nsf/DocDetails.xsp?id=WDU20180000753

13. Państwowa inspekcja sanitarna (2018) ABC szczepienia ochronne. Praktyczny poradnik dla rodziców dzieci do 2. roku życia. Pobrane z: https://gis. gov.pl/wp-content/uploads/2018/04/ABC-Szczepienia-ochronne-1-1.pdf

14. Solecka M. (2016) Czterech jeźdźców apokalipsy. Pobrane z: https://www.mp.pl/szczepienia/specjalne/137347,czterech-jezdzcow-proepidemicznej-apokalipsy 
15. Chang M.H, et al. Long-term effects of hepatitis B immunization of infants in preventing liver cancer. Gastroenterology, 2016; 151; 472-480.

16. Rywczak I. (2017) Ryzyko związane ze szczepieniami i chorobami, którym zapobiegają - cz. 5: poliomyelitis. Pobrane z: https://www.mp.pl/ szczepienia/artykuly/przegladowe/161934,ryzyko-zwiazane-ze-szczepieniami-i-chorobami-ktorym-zapobiegaja-poliomyelitis

17. European Centre for Disease Prevention and Control (2018) Measles cases in the EU treble in 2017, outbreaks still ongoing. Pobrane z: https://ecdc.europa.eu/en/news-events/measles-cases-eu-treble2017-outbreaks-still-ongoing

18. European Centre for Disease Prevention and Control (2018) Measles and rubella surveillance - 2017. Pobrane z: https://ecdc.europa.eu/en/publications-data/annual-measles-and-rubella-monitoring-report-2017
19. Narodowy Instytut Zdrowia Publicznego. Państwowy Zakład Higieny. (2019) 5-krotny wzrost zachorowań na odrę w 2018 roku. Pobrane z: http://szczepienia.pzh.gov.pl/5-krotny-wzrost-zachorowan-na-odre-w-2018-roku/

Received: 18.09.2019

Accepted for publication: 12.03.2020

Otrzymano: 18.09.2019 r.

Zaakceptowano do publikacji: $12.03 .2020 \mathrm{r}$.

\section{Adres do korespondencji:}

Address for correspondence:

Lek. Mateusz Szczupak

Copernicus PL Sp. z o.o.

Oddział Chorób Wewnętrznych i Hipertensjologii

ul. Nowe Ogrody 1-6, 80-803 Gdańsk

tel: 607665733

e-mail: szczupak.mateusz@gmail.com 